\title{
Morphometric Relationships of franciscana dolphin, Pontoporia blainVillei (Cetacea), off Rio Grande do Sul coast, southern Brazil
}

\author{
Silvina Botta ${ }^{1, *}$, Mônica M. C. Muelbert ${ }^{1}$ And Eduardo R. Secchi ${ }^{1,2}$
}

\begin{abstract}
Aвstract: Due to the limited availability of cetaceans, body mass as a measurement of body size is often hard to estimate resulting in reduced sample sizes. Therefore, models for estimating body mass from an analysis of morphometric relationships are useful and practical tools to overcome such difficulties. In the present work, we propose specific models to estimate body mass from morphometric variables of franciscanas inhabiting Rio Grande do Sul, southern Brazil. A total of 226 franciscanas (130 males and 96 non-pregnant females) of all size classes, incidentally caught from 1994 to 2005 off Rio Grande do Sul coast $\left(31^{\circ} 13^{\prime} \mathrm{S}-33^{\circ} 45^{\prime} \mathrm{S}\right)$, were examined. Body mass (BM in $\mathrm{kg}$ ) was regressed against total length (TL in $\mathrm{cm}$ ), maximum girth (MG in $\mathrm{cm})$ and a body-volume index: $\mathrm{BV}\left(\mathrm{cm}^{3}\right)=\mathrm{TL}(\mathrm{cm}) \times(\mathrm{MG}(\mathrm{cm}))^{2}$. Although linear regressions of body mass on both TL and MG were reliable predictors, a combination of those linear measurements to obtain a body volume index proved to be the best estimator of body mass. Models are the following: $B M=3.68^{*} 10^{-5} B V$ for males; $B M=3.64^{*} 10^{-5} B V$ for females and $B M=3.66^{*} 10^{-5} B V$ for sexes combined. Models presented were valuable methods for indirect body mass estimation for franciscana. Due to the similiarity in the body volume-body mass ratio in males and females, the mixed sexes combined model was deemed most appropriate for estimating body mass. This technique should be of great help in field situations where obtaining body mass is often difficult and sometimes impossible. Developing similar models for franciscanas from the other regions is recommended.

Resumo: A massa corporal em cetáceos, como uma medida indicadora do tamanho corporal, é um parâmetro de difícil obtenção em algumas circunstâncias. Isso resulta em um número reduzido de amostras para estudos de massa corporal. Assim, os modelos para estimar massa corporal a partir de relações biométricas podem ser ferramentas práticas de grande utilidade. Nesse trabalho são propostos modelos específicos para estimar massa corporal a partir de variáveis morfométricas das toninhas do Rio Grande do Sul, sul do Brasil. Foram examinadas 226 espécimens (130 machos e 96 fêmeas não grávidas) capturados acidentalmente entre 1994 e 2005 na costa do Rio Grande do Sul (31 $\left.13^{\circ} \mathrm{S}-33^{\circ} 45^{\prime} \mathrm{S}\right)$, incluindo todas as classes de tamanho. A massa corporal (MC em $\mathrm{kg}$ ) foi correlacionada ao comprimento total $(\mathrm{CT}$ em $\mathrm{cm})$, circunferência máxima $(\mathrm{CM}$ em $\mathrm{cm})$ e um índice de volume corporal $\left(\mathrm{VC}\right.$ em $\mathrm{cm}^{3}=\mathrm{CT}(\mathrm{cm}) \times(\mathrm{CM}(\mathrm{cm}))^{2}$. As regressões da massa corporal com o $\mathrm{CT}$ e CM foram bons preditores. Porém, comprovou-se que a combinação dessas medidas lineares para obter um índice de volume corporal foi o melhor estimador de massa corporal. Os modelos são os seguintes: $M C=3.68^{*} 10^{-5} \mathrm{VC}$ para os machos; $M C=3.64^{*} 10^{-5} \mathrm{VC}$ para as fêmeas e $M C=3.66^{*} 10^{-5} V C$ para os sexos combinados. Devido à similaridade na relação volume corporal-massa corporal dos machos e fêmeas, recomenda-se a utilização do modelo de sexos combinados. Os modelos apresentados são um método eficaz de estimar a massa corporal de forma indireta. Essa técnica pode ser útil em trabalho de campo em que a obtenção da massa corporal é geralmente difícil e algumas vezes impossível. Recomenda-se o desenvolvimento de modelos similares para as toninhas de outras regiões.
\end{abstract}

KeYwords: Pontoporia blainvillei, franciscana, morphometrics, length-weight relationship, sexual dimorphism.

\section{Introduction}

The franciscana dolphin (Pontoporia blainvillei) is endemic to the southwestern Atlantic. Its occurrence is well documented throughout its range, which extends from Itaúnas in Espirito Santo, Brazil, to Golfo Nuevo in Chubut, Argentina (Crespo et al., 1998; Siciliano et al., 2002). It has been extensively captured in coastal gillnets throughout its range (Corcuera, 1994; Secchi et al., 1997; Pinedo and Polacheck, 1999; Di Beneditto and Ramos, 2001; Bertozzi and Zerbini, 2002; Kinas, 2002; Ott et al., 2002; Rosas et al., 2002; Secchi et al., 2003b). The distribution is discontinuous, as two hiatuses occur: one in southern Espírito Santo state, and the other between Macaé (southern Rio de Janeiro state) and Ubatuba (northern São Paulo state) (Siciliano et al., 2002) (Figure 1). For management purposes, four Franciscana Management Areas (FMA) have been recently proposed (Secchi et al., 2003a). Life history traits (especially body size) vary among individuals from these areas. Franciscanas inhabiting the southern end of this range are larger than the individuals from the northern end. Conversely, individuals from the central area of distribution are the smallest of all (Pinedo, 1991, 1995; Ramos et al., 2002; Barreto and Rosas, 2006).

Body size affects all aspects of an organism's physiology and morphology, thereby influencing life history traits (e.g. Stearns, 1983; Calder, 1984; Lindstedt and Swain, 1988). It also is the most fundamental character of an individual in limiting its morphological aspects and structural dimensions (Lindstedt and Swain, 1988; Begon et al., 1990; Smith et al., 2001). Body mass, as a measurement of body size, is often hard to estimate in marine mammals because of the inherent difficulty in handling large wild animals as well as other logistical

\footnotetext{
${ }^{1}$ Laboratório de Tartarugas e Mamíferos Marinhos, Departamento de Oceanografia, Fundação Universidade Federal do Rio Grande (FURG). Avenida Itália km 8, Caixa Postal 474, Rio Grande, 96201-900 RS Brazil.

${ }^{2}$ Laboratório de Mamíferos Marinhos, Museu Oceanográfico “Eliézer de C. Rios” - FURG. Caixa Postal 379, Rio Grande, $96200-970$ RS Brazil.

* Corresponding author, e-mail: silvinabotta@furg.br.
} 
constraints (Haley et al., 1991; Bell et al., 1997; Ireland et al., 2006). This is especially true for cetaceans due to their limited availability often resulting in reduced sample sizes. Therefore, models for estimating body mass from morphometric relationships are useful and practical tools to overcome such difficulties.

Models for mass estimation in marine mammals have been developed for some large pinnipeds \{e.g. Steller sea lions, Eumetopias jubatus, Castellini and Calkins (1993); northern elephant seals, Mirounga angustirotris, Haley et al. (1991); southern elephant seals, Mirounga leonina, Bell et al. (1997); Weddell seals, Leptonychotes weddellii, Ireland et al. (2006)) and cetaceans (fin and sei whales, Balaenoptera physalus and B. borealis, Lockyer and Waters (1986); bottlenose dolphins, Tursiops truncatus, Read et al. (1993); harbour porpoises, Phocoena phocoena, Lockyer (1995); Read and Tolley (1997); killer whales, Orcinus orca, Clark et al. (2000); estuarine dolphins, Sotalia guianensis, Rosas et al. (2003)). In the case of the franciscana, mass estimation models can be found in the literature, but consist solely of simple regressions of mass versus total length (Kasuya and Brownell, 1979; Rosas, 2000; Rodriguez et al., 2002; Botta, 2005) and do not account for seasonal or developmental variations in body mass. Models which include both length and girth measurements as predictor variables are most reliable (Lockyer and Waters, 1986; Read et al., 1993; Lockyer, 1995; Read and Tolley, 1997;
Clark et al., 2000). In the present work we propose specific models to estimate body mass from morphometric variables of franciscanas inhabiting Rio Grande do Sul, southern Brazil.

\section{Material and Methods}

A total of 226 franciscanas (130 males and 96 nonpregnant females) of all size classes, incidentally caught from 1994 to 2005 off Rio Grande do Sul coast, southern Brazil (31 $\left.13^{\circ} \mathrm{S}-33^{\circ} 45^{\prime} \mathrm{S}\right)$, were examined (Figure 2). Franciscana carcasses were brought by local fishermen and stored on ice or frozen prior to necropsy. Recorded information included sex, body mass (BM in $\mathrm{kg}$ ), total length (TL in $\mathrm{cm}$ ) and maximum girth (MG in $\mathrm{cm}$ ). Total length was measured parallel to the body axis from the foremost point of the rostrum to the fluke notch and maximum girth was measured immediately in front of the dorsal fin (Norris, 1961). Length and girth measurements were used to predict body mass using nonlinear regression. Multiple linear regression equations were examined after log-transformation of model variables. The body-volume index (BV) was calculated using the formula: BV $\left(\mathrm{cm}^{3}\right)=\mathrm{TL}(\mathrm{cm}) \times(\mathrm{MG}(\mathrm{cm}))^{2}$ (Castellini and Calkins, 1993) and was linearly regressed against body weight. All models were developed for males and females separately and for sexes combined.

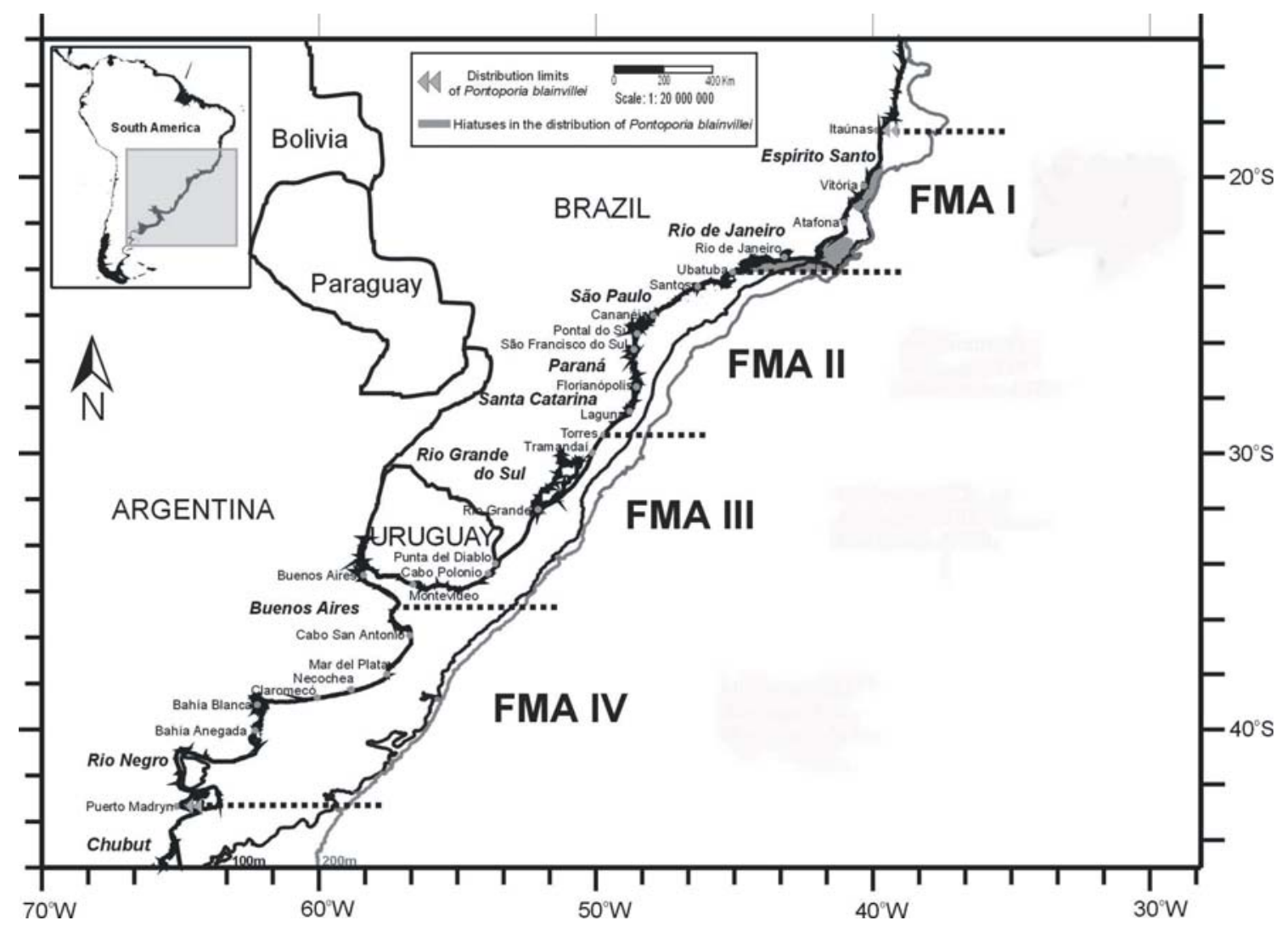

Figure 1. Distribution of franciscana (Pontoporia blainvillei) and Franciscana Management Areas (FMAs) (modified from Secchi et al., 2003a). 


\section{Results}

For both sexes, this franciscana sample was largely composed of animals from cold and warm weather months (July to December) (Figure 3). Mean ( $\pm 1 \mathrm{sd}$ ) female weight was $23.701 \pm 7.232 \mathrm{~kg}(N=93)$, mean total length and maximum girth were $123.578 \pm 17.152 \mathrm{~cm}$ $(N=96)$ and $70.656 \pm 8.003 \mathrm{~cm}(N=92)$, respectively. Mean male weight was $22.455 \pm 5.817 \mathrm{~kg}(N=129)$, mean total length was $120.354 \pm 14.058 \mathrm{~cm}(N=130)$ and mean maximum girth was $69.144 \pm 7.459 \mathrm{~cm}(N=116)$.

The coefficient of determination $\left(\mathrm{r}^{2}\right)$ between the variables body mass and total length indicated the model explained a significant portion $(85 \%)$ of the variability in body mass using total length, this was more so with females than males $(92 \%$ versus $78 \%$, respectively) (Table 1 ). The prediction strength of regression equations between body mass and maximum girth were lower than previous models in all categories (Table 1). Here again, the strength of the female model was greater in its predictive power than the male $\left(\mathrm{r}^{2}=\right.$ 0.78 versus 0.74 , respectively). Multiple linear regression techniques utilizing log-transformed variables served to increase the predictive power of the models (Table 1 , $\# 7$, \#9 and \#11). However, it was the body volume index that proved to be the superior body mass estimator resulting in significant increases in $\mathrm{r}^{2}$ across all categories (Table 1, \#8, \#10 and \#12; Figure 4).

Furthermore, in the case of females, sex-specific models did not improve estimations, but did so in the case of males.

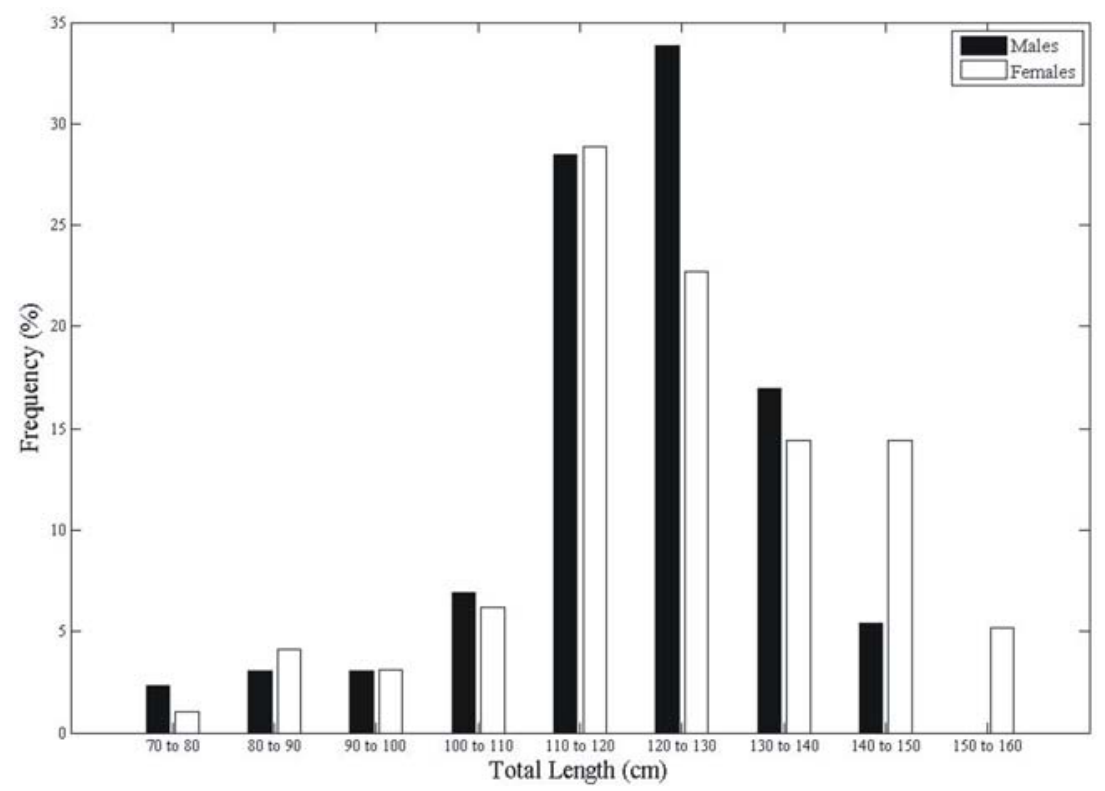

Figure 2. Size classes frequency distribution of franciscanas (Pontoporia blainvillei) from Rio Grande do Sul, southern Brazil.

Figure 3. Sex distribution of franciscanas (Pontoporia blainvillei) samples from Rio Grande do Sul, southern Brazil.

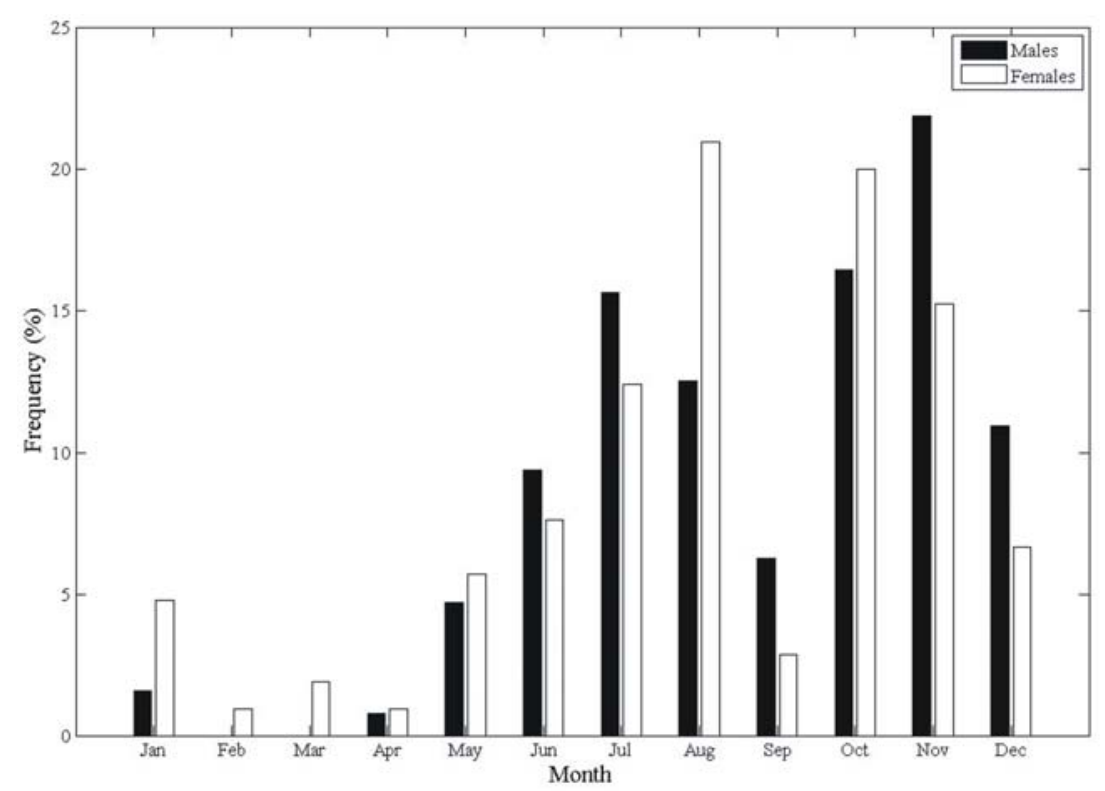


Table 1. Models for body mass (BM) estimation for females, males and sexes combined of franciscanas (Pontoporia blainvillei) from Rio Grande do Sul, southern Brazil.

\begin{tabular}{|c|c|c|c|c|}
\hline MODEL \# & SEX & MODEL DESCRIPTION & $\mathrm{r}^{2}$ & $\mathrm{n}$ \\
\hline$\# 1$ & $\sigma^{\prime}$ & $B M=8.37^{*} 10^{-4} T L^{2.1244}$ & 0.78 & 127 \\
\hline$\# 2$ & 오 & $B M=9.63^{*} 10^{-4} T L^{2.0934}$ & 0.92 & 90 \\
\hline \#3 & $\delta$ and $P$ & $B M=1.1^{*} 10^{-3} T L^{2.0666}$ & 0.85 & 217 \\
\hline$\# 4$ & $\sigma^{\prime}$ & $B M=2.22^{*} 10^{-3} M G^{2.1682}$ & 0.74 & 114 \\
\hline$\# 5$ & 오 & $B M=9.8^{*} 10^{-4} M G^{2.3635}$ & 0.78 & 87 \\
\hline \#6 & o" and 우 & $B M=1.12^{*} 10^{-3} M G^{2.3299}$ & 0.76 & 201 \\
\hline $\begin{array}{l}\# 7 \\
\# 8\end{array}$ & $\sigma^{\prime}$ & $\begin{array}{l}\log B M=-7.99+1.32 \log T L+1.12 \log M G \\
B M=3.68^{\star} 10^{-5} \mathrm{BV}\end{array}$ & $\begin{array}{l}0.89 \\
0.99\end{array}$ & 114 \\
\hline $\begin{array}{l}\# 9 \\
\# 10\end{array}$ & 오 & $\begin{array}{l}\log B M=-7.92+1.68 \log T L+0.70 \log M G \\
B M=3.64^{*} 10^{-5} B V\end{array}$ & $\begin{array}{l}0.93 \\
0.99\end{array}$ & 87 \\
\hline \#11 & $\sigma$ and 9 & $\begin{array}{l}\log B M=-8.03+1.49 \log T L+0.94 \log M G \\
B M=3.66^{*} 10^{-5} \mathrm{BV}\end{array}$ & $\begin{array}{l}0.91 \\
0.99\end{array}$ & 201 \\
\hline
\end{tabular}

\section{Discussion}

Body weight of franciscanas was reasonably estimated from their body length or maximum girth, but better predictions could be done by using both variables in a multiple regression equation on log-transformed data. However, the best results were obtained by combining them in a single predictor, the body volume index. These findings confirmed previous cetacean studies where the best predictions of body mass value were obtained from equations involving both length and girth (Doidge, 1990; Read et al., 1993; Lockyer, 1995; Read and Tolley, 1997; Clark et al., 2000). Time of sampling may influence weight-length relationships through seasonal changes in body condition, thus the inclusion of girth in the equations used for indirect mass estimation is desirable. Therefore, when weighing animals proves impossible, it is recommended to take both length and girth measurements, although if not possible at least one of them (preferably total length) should be measured. Due to effects of decomposition and handling problems, girths of stranded cetaceans are often not measured (Stolen et al., 2002) and although the least reliable of all predictors, it can be useful in situations when carcasses are damaged and total length cannot be measured (Lockyer, 1995). This result differed from previous studies on other species where girth was a better predictor of body mass than length for both males and females (Read et al., 1993; Lockyer, 1995). Franciscanas exhibit a high degree of reverse sexual dimorphism in body size (Kasuya and Brownell, 1979; Brownell, 1989; Pinedo, 1991, 1995). However, we found almost no differences in morphometric relationships between male and females as male and female body volume-total length regression equation slope coefficients were virtually identical: $3.68^{*} 10$ ${ }^{5}$ versus $3.64^{*} 10^{-5}$, respectively. This suggested a model based upon a single sample of both sexes, with its increased precision due to larger sample size, may be preferable.

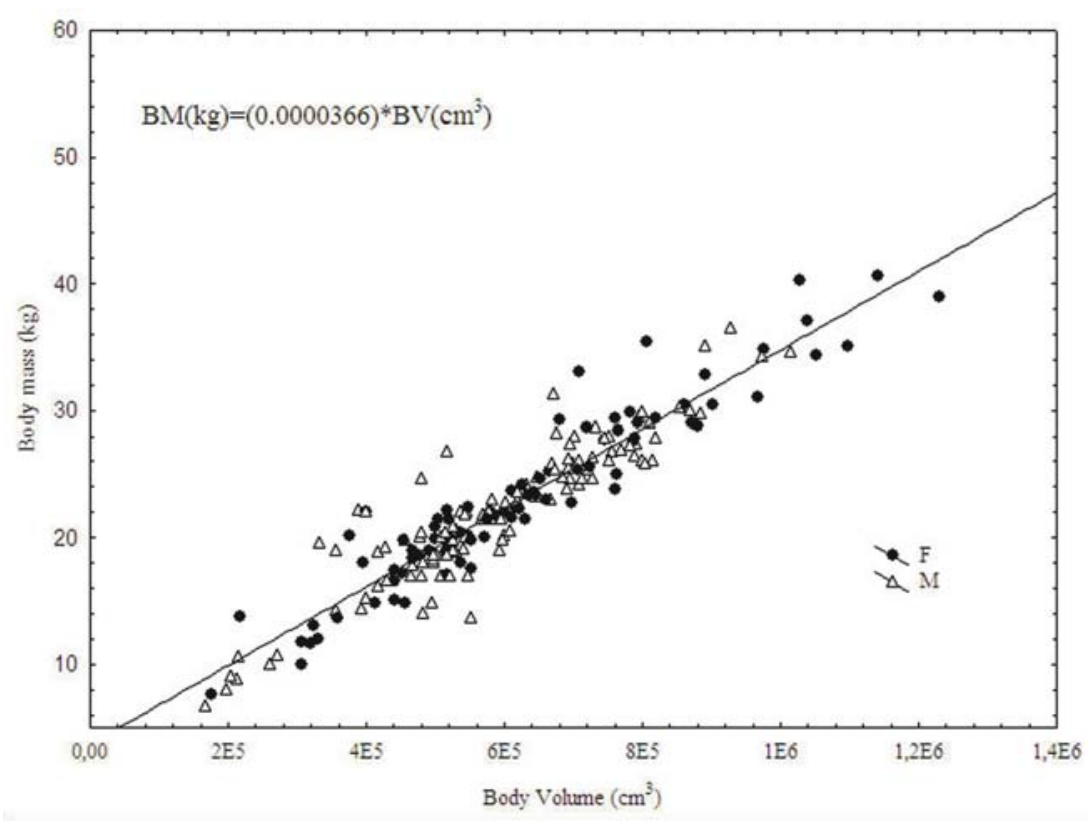

Figure 4. Body mass (BM) on body volume index (BV) of male and female franciscanas (Pontoporia blainvillei) from Rio Grande do Sul, southern Brazil. 
Several morphometric and genetic studies (Pinedo, 1991, 1995; Secchi et al., 1998, 2003a; Ott et al., 2002; Ramos et al., 2002; Lázaro et al., 2004; Barreto and Rosas, 2006) have established the existence of three franciscana morphotypes/genotypes: one found in FMA I (Rio de Janeiro and Espírito Santo states, Brazil); a second one in FMA II (from São Paulo to Santa Catarina states, Brazil) and the third in FMA III and IV (from Rio Grande do Sul state, Brazil down to Buenos Aires Province, Argentina). Animals inhabiting FMA I are smaller than animals from FMA III and IV but larger than those from FMA II. Some previous work on length-weight relationships in cetaceans tried to find a general pattern of body length-body weight ratio along a wide range of sizes (Gihr and Pilleri, 1979). Taking this apparent general law that governs this ratio into account it is expected that the equations obtained from animals from one morphotype/genotype should serve to accurately estimate body mass of franciscanas from other management stocks. Length-weight relationships for franciscana dolphins are only known for animals inhabiting FMA II (Rosas, 2000). As can be corroborated in Figures 5 and 6, equations developed for male and female franciscanas from São Paulo and Paraná states (FMA II, Rosas, 2000) underestimated body mass for animals from Rio Grande do Sul state. Then, our results confirmed individuals from FMA II with same length are more slender than franciscanas from Rio Grande do Sul (FMA III) so the hypothesis of a general valid law for all franciscana management groups is rejected, at least for FMA II and FMA III.

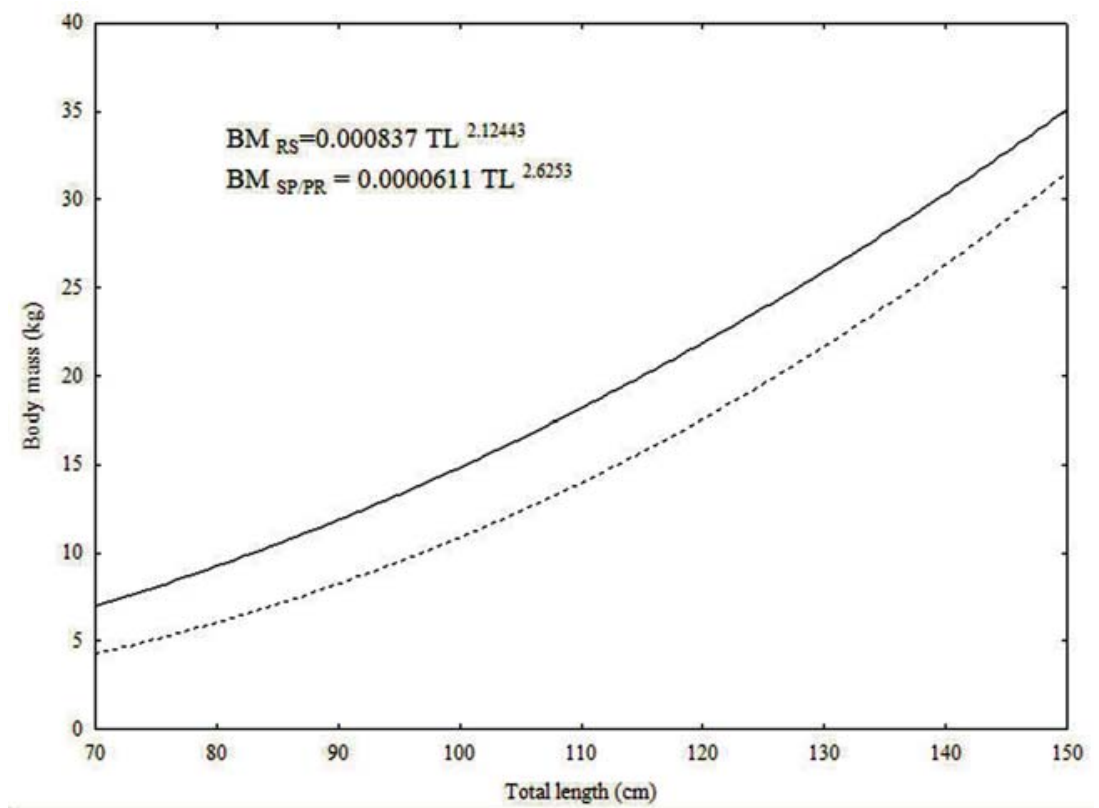

Figure 5. Models for estimating body mass (BM) from total length (TL) of male franciscanas (Pontoporia blainvillei) from Rio Grande do Sul (RS, solid line) and São Paulo and Paraná states (SP/PR, dashed line), Brazil.

Figure 6. Models for estimating body mass (BM) from total length (TL) of female franciscanas (Pontoporia blainvillei) from Rio Grande do Sul(RS, solid line) and São Paulo and Paraná states (SP/PR, dashed line), Brazil.

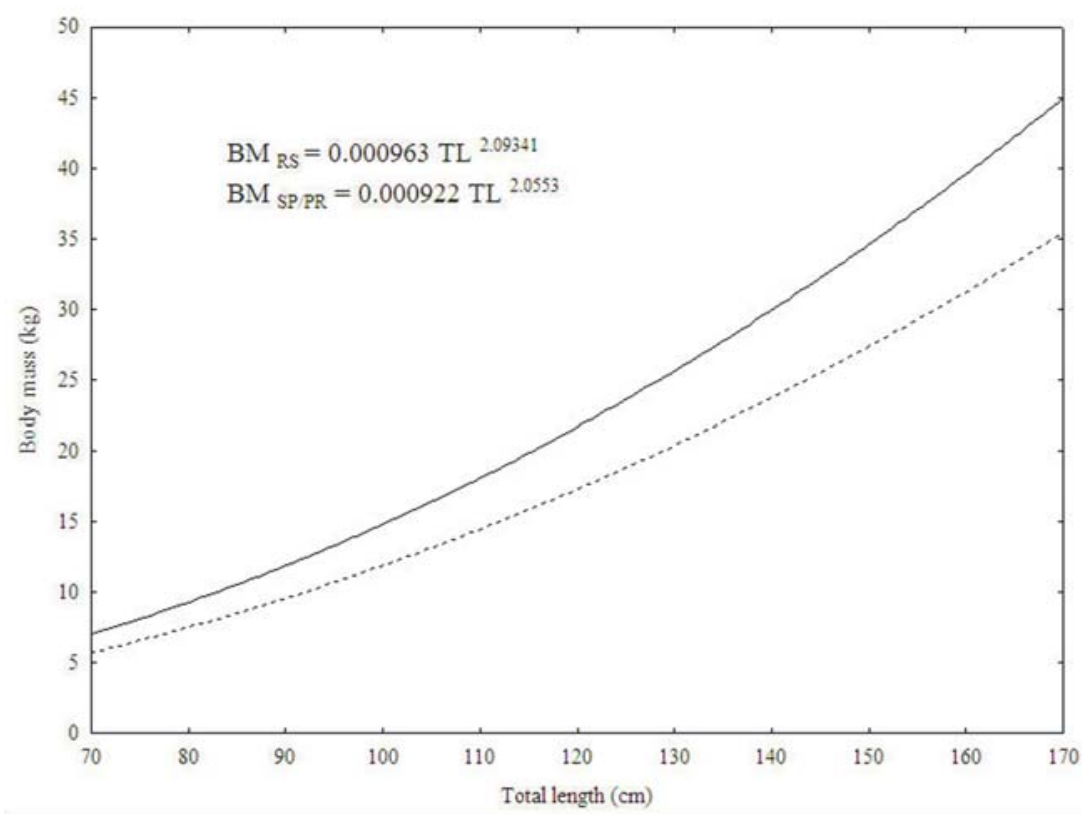


Models presented here proved to be a valuable method of indirect body mass estimation for franciscana. This technique should be of great help in the field (e.g. beach surveys for carcasses recovering) and is particularly useful in the study area due to the high frequency events of franciscana's massive mortality where weighing all animals is difficult if not impossible. Furthermore, carcasses found during beach surveys are usually in a high degree of decomposition (especially during warmer months) thus limiting the reliability of direct weighing (equations presented here were developed from measurements of incidentally caught fresh animals). Developing similar models for franciscanas from the other regions is recommended. Further, it is important to note that models should be elaborated, whenever possible, based on incidentally captured animals as they probably represent healthy specimens. Animals stranded or that have died in captivity might have below-average weights.

\section{Acknowledgments}

This study could not have been made without the cooperation of the fishermen from Rio Grande. Many people collaborated in the collection and necropsy of the dolphins and the authors wish to thank Manuela Bassoi, Alexandre Zerbini, Luciana Möller, Luciano Dalla Rosa, Lilia Fidelix, Juliana Di Tullio, Emanuel Ferreira and numerous volunteers for helping in this task. The authors also thank Lauro Barcellos (Director of the Museu Oceanográfico) for his constant logistical support and for encouraging marine mammal studies in southern Brazil. Financial support was given by Fundo Nacional do Meio Ambiente (FNMA) and Yaqu Pacha Foundation. Steven T. Clark and Andrew Westgate provided important suggestions to improve the manuscript.

\section{References}

BARRETO, A.S. AND Rosas, F.C.W. (2006) Comparative growth analysis of two populations of Pontoporia blainvillei on the Brazilian coast. Marine Mammal Science 22: 644-653.

Begon, M., Harper, J.L. And TownSEnd, C.R. (1990) Ecology. Individuals, Populations and Communities. Blackwell Scientific Publications, London, United Kingdom.

Bell, C.M., Hindell, M.A. ANd Burton, H.R. (1997) Estimation of body mass in the southern elephant seal, Mirounga leonina, by photogrammetry and morphometrics. Marine Mammal Science 13: 669-682.

BertozZI, C.P. ANd ZeRBINI, A.N. (2002) Incidental mortality of toninha (Pontoporia blainvillei) in the artisanal fishery of Praia Grande, São Paulo state, Brazil. The Latin American Journal of Aquatic Mammals (special issue)1: 153-160.

BotTA, S. (2005) Reprodução e crescimento dos machos de toninha (Pontoporia blainvillei) do Rio Grande do Sul, Brasil. M.Sc. Thesis. Fundação Universidade Federal do Rio Grande, Rio Grande, RS, Brazil. 108 pp.
Brownell, R.L. (1989) Franciscana Pontoporia blainvillei (Gervais \& d'Orbigny, 1844). Pages 45-67 in Ridghay, S.H. AND HARRISON, R. (Eds). Handbook of Marine Mammals, Vol.4: River dolphins and the larger toothed whales. Academic Press, San Diego, CA. USA.

CAlder, W.A. (1984) Size, Function, and Life History. Harvard University Press. Cambridge, MA, USA.

CAON, G. (1998) Análise da condição corporal da franciscana, Pontoporia blainvillei (Gervais \& D’Orbigny, 1844) (Mammalia, Cetácea) no litoral norte do Rio Grande do Sul. BSc. Thesis. Universidade Federal do Rio Grande do Sul. Porto Alegre, RS, Brazil. 21 pp.

CAstellini, M.A. And CalKins, D.G. (1993) Mass estimates using body morphology in Steller sea lions. Marine Mammal Science 9: 48-54.

Clark, S.T., Odell, D.K. and LacinaK, C.T. (2000) Aspects of growth in captive killer whales (Orcinus orca). Marine Mammal Science 16: 110-123.

Corcuera, J. (1994) Mortality of Pontoporia blainvillei in northern Buenos Aires Province: the threat of small fishing camps. Reports of the International Whaling Commission (special issue) 15: 291-294.

Crespo, E.A., Harris, G. and González, R. (1998) Group size and distribution range of the franciscana, Pontoporia blainvillei. Marine Mammal Science 14: 845-849.

Di Beneditto, A.P.M. and Ramos, R.M.A. (2001) Biology and conservation of the franciscana (Pontoporia blainvillei) in the north of Rio de Janeiro state, Brazil. Journal of Cetacean Research and Management 3: 185-192.

Doidge, D.W. (1990) Age - length and weight - length comparisons in the beluga (Delphinapterus leucas). Canadian Bulletin of Fisheries and Aquatic Sciences 224: 58-68.

GIHR, M. AND PILLERI, G. (1979) Interespecific body length-body weight ratio and body weight-brain weght ratio in Cetacea. Investigations on Cetacea 10: 245-253.

Haley, M.P., Deutsch, C.J. And Le Boeuf, B.J. (1991) A method for estimating mass of large pinnipeds. Marine Mammal Science 7: $157-164$.

Hohn, A.A., Read, A.J., Fernandez, S., Vidal, O. and Findley, L.T. (1996) Life history of the vaquita, Phocoena sinus (Phocoenidae, Cetacea). Journal of Zoology 239: 235-251.

Ireland, D., Garrott, R.A., Rotella, J. AND BANFIELD, J. (2006) Development and application of a mass-estimation method for Weddell seals. Marine Mammal Science 22: 361-378.

Kastelein, R.A., Hardeman, J. and Boer, H. (1997) Food consumption and body weight of harbour porpoises (Phocoena phocoena). Pages 217-233 in Read, A.J., WiePKema, P.R. AND Nachtigall, P.E. (Eds) The biology of the harbour porpoise. De Spil Publishers, Woerden, The Netherlands.

KasuYa, T. AND Brownell, R.L. (1979) Age determination, reproduction, and growth of the franciscana dolphin, Pontoporia blainvillei. Scientific Reports of the Whales Research Institute 31: 45-67.

KINAS, P.G. (2002) The impact of incidental kills by gill nets on the franciscana dolphin (Pontoporia blainvillei) in southern Brazil. Bulletin of Marine Science 70: 409-421.

Lázaro, M., Lessa, E.P. and Hamilton, H. (2004) Geographic genetic structure in the franciscana dolphin (Pontoporia blainvillei). Marine Mammal Science 20: 201-214. 
LindSTEDT, S.L. AND SwaIn, S.D. (1988) Body size as a constraint of design and function. Pages 93-105 in Boyce, M.S. (Ed.) Evolution of Life Histories of Mammals. Theory and Pattern. Yale University Press, New Heaven and London.

LOCKYER, C. AND WATERS, T. (1986) Weigths and anatomical measurements of northeastern Atlantic fin (Balaenoptera physalus, Linnaeus) and sei (B. borealis, Lesson) whales. Marine Mammal Science 2: 169-185.

LOCKYER, C. (1995) Aspects of the morphology, body fat condition and biology of the harbour porpoise, Phocoena phocoena, in British waters. Report of the International Whaling Commision (special issue) 16: 199-209.

NoRRIS, K.S. (1961) Standardized methods for measuring and recording data on the smaller cetaceans. Journal of Mammalogy 42: 471-476.

Ott, P.H., Secchi, E.R., Moreno, I.B., Danilewicz, D., Crespo, E.A., Bordino, P., Ramos, R., Di Beneditto, A.P., Bertozzi, C., Bastida, R., Zanelatto, R., Perez, J.E. and Kinas, P.G. (2002) Report of the working group on fishery interactions. The Latin American Journal of Aquatic Mammals (special issue) 1: 55-64.

PInedo, M.C. (1991) Development and variation of the franciscana, Pontoporia blainvillei. Ph.D. Thesis. University of California. Santa Cruz, CA, USA. 406 pp.

PINEDO, M.C. (1995) Development and variation in external morphology of the franciscana, Pontoporia blainvillei. Revista Brasileira de Biologia 55:85-96.

Pinedo, M.C. And Polacheck, T. (1999) Trends in franciscana (Pontoporia blainvillei) stranding rates in Rio Grande do Sul, southern Brazil (1979-1998). Journal of Cetacean Research and Management 1: 179-189.

Ramos, R.M.A., Di Beneditto, A.P.M and Lima, N.R.W. (2000) Growth parameters of Pontoporia blainvillei and Sotalia fluviatilis (Cetacea) in northern Rio de Janeiro, Brazil. Aquatic Mammals 26: 65-75.

RAMOS, R.M.A., Di Beneditto, A.P.M., SicILIANO, S., SANTOS, M.C.O., Zerbini, A.N., Bertozzi, C., Vicente, A.F.C., Zampirolli, E., Alvarenga, F.S. And Lima, N.R.W. (2002) Morphology of the franciscana (Pontoporia blainvillei) off the southeastern Brazil: sexual dimorphism, growth and geographical variation. The Latin American Journal of Aquatic Mammals (special issue)1: 129-144.

Read, A.J., Wells, R.S., Hohn, A.A. And Scott, M.D. (1993) Patterns of growth in wild bottlenose dolphins, Tursiops truncatus. Journal of Zoology, London 231: 107-123.

Read, A.J. And Tolley, K.A. (1997) Postnatal growth and allometry of harbour porpoises from the Bay of Fundy. Canadian Journal of Zoology 75: 122-130.

RodrigueZ, D., Rivero, L. AND BASTIDA, R. (2002) Feeding ecology of the franciscana (Pontoporia blainvillei) in marine and estuarine waters of Argentina. The Latin American Journal of Aquatic Mammals (special issue ) 1:77-94.

Rosas, F.C.W. (2000) Interações com a pesca, mortalidade, idade, reprodução e crescimento de Sotalia guianensis $e$ Pontoporia blainvillei (Cetacea, Delphinidae e Pontoporiidae) no litoral sul do Estado de São Paulo e litoral do Estado do Paraná, Brasil. Ph.D. Thesis. Universidade Federal do Paraná.Curitiba, PR, Brazil. 145 pp.

Rosas, F.C.W., Monteiro Filho, E.L.A. And Oliveira, M.R. (2002) Incidental catches of franciscana (Pontoporia blainvillei) on the southern coast of São Paulo state and the coast of Paraná state, Brazil. The Latin American Journal of Aquatic Mammals (special issue) 1: 161-167.

Rosas, F.C.W., Barreto, A.S. And Monteiro Filho, E.L.A. (2003) Age and growth of the estuarine dolphin (Sotalia guianensis) (Cetacea, Delphinidae) on the Paraná coast, southern Brazil. Fishery Bulletin 101: 377-383.

Secchi, E.R., Zerbini, A.N., BassoI, M., Dalla Rosa, L., Moller, L.M. AND Rocha-CAmPOS, C.C. (1997) Mortality of franciscanas, Pontoporia blainvillei, in coastal gillnetting in southern Brazil: 19941995. Reports of the International Whaling Commission 47: 653-658.

Secchi, E.R., Wang, J.Y., Murray, B., Rocha-Campos, C.C. And White, B.N. (1998) Population differentiation in the franciscana (Pontoporia blainvillei) from two geographic locations in Brazil as determined from mitochondrial DNA control region sequences. Canadian Journal of Zooolgy 76: 1622-1627.

Secchi, E.R., Danilewicz, D. And OtT, P.H. (2003a) Applying the phylogeographic concept to identify franciscana dolphin stocks: implications to meet management objectives. Journal of Cetacean Research and Management 5: 61-68.

Secchi, E.R., Ott, P.H. AND Danilewicz, D.S. (2003b) Effects of fishing bycatch and conservation status of the franciscana dolphin, Pontoporia blainvillei. Pages 174-191 in Gales, N., Hindell, M. And Kirkwood, R. (Eds) Marine Mammals: Fisheries, Tourism and Management Issues. CSIRO Publishing, Collingwood, Australia.

Siciliano, S., Di Beneditto, A.P.M. and Ramos, R.M.A. (2002) A toninha, Pontoporia blainvillei (Gervais \& d’Orbigny, 1844) (Mammalia, Cetacea. Pontoporiidae), nos estados do Rio de Janeiro e Espírito Santo, costa sudeste do Brasil: caracterização dos hábitats e fatores de isolamento das populações. Boletim do Museu Nacional, Nova Série, Zoologia 476: 1-15.

Smith, F.A., Brown, J.H., Haskell, J.P., Lyons, S.K., Alroy, J., Charnov, E.L., Dayan, T., Enquist, B.J., Ernest, S.K.M., Hadly, E.A., Jones, K.E., Kaufman, D.M., Marquet, P.A., Maurer, B.A., Nildas, K.J., Porter, W.P., Tiffney, B. And Willig, M.R. (2001) Similarity of mammalian body size across the taxonomic hierarchy and across space and time. The American Naturalist 163: 672-691.

STEARNS, S.C. (1983) Influence of size and phylogeny on patterns of covariation among life-history traits in the mammals. Oikos 41:173-187.

Stolen, M.K., Odell, D.K. and Barros, N.B. (2002) Growth of bottlenose dolphins (Tursiops truncatus) from the Indian River lagoon system, Florida, U.S.A. Marine Mammal Science 18: 348-357. 